\title{
A more efficient derivative action system in China: challenges and opportunities through corporate governance theory \\ DR JINGCHEN ZHAO*
}

University of Sussex

\begin{abstract}
$\underline{\text { Abstract }}$
The derivative action is an exception to the rule in Foss $\mathrm{v}$ Harbottle ${ }^{1}$ that was introduced with high expectations during a Chinese company law (CCL) reform that came into effect in 2006. It is vital to combat the abuse of derivative action in China, a country with an emerging corporate governance model, a weak legal system and inefficient enforcement measures. This article examines several deficiencies in derivative actions, with the purpose of arguing for a more effective and positive derivative action rule for the benefit of shareholders and their companies, and also for the development of CCL and the reconstruction of the Chinese corporate governance system. Corporate governance theories will be discussed as theoretical supports for a more efficient and enforceable derivative action system in China.
\end{abstract}

Key words: China; company law; corporate governance; derivative claim; shareholders.

\section{Introduction}

$\mathrm{T}$ The rule in Foss $v$ Harbottle ${ }^{2}$ provides a negative answer to the question of whether an individual shareholder is able to bring a complaint before the court if an irregularity has been committed in the course of a company's affairs, or if some wrong has been done to the company. Derivative action is an exception to the rule in English law that defines the company itself as the proper person or legal entity to bring action when seeking redress against wrongdoers who are in control of the company. Statutory derivative action is designed to overcome inadequacies of common law in the area of shareholder remedies, including the prohibitive cost of litigation, the restrictive standing requirement, and uncertainties concerning the rule and its exceptions. ${ }^{3}$ However, it may also lead to manifest injustices when it goes wrong, not only due to the essence and logic of the law but also to the efficiency and defects of the procedure itself. ${ }^{4}$ Derivative action provides that if a

* Senior Lecturer in Corporate and Commercial Law, University of Sussex, Jingchen.Zhao@sussex.ac.uk. I am grateful for the comments of an anonymous referee.

1 Foss v Harbottle (1843) 2 Hare 461.

2 Ibid.

3 I M Ramsay and B B Saunders, 'Litigation by Shareholders and Directors: An Empirical Study of the Statutory Derivative Action' (Melbourne Law School Legal Studies Research Paper No 250, Centre for Corporate Law and Securities Regulation, University of Melbourne 2006) 10-14.

4 See C Hale, 'What's Right with the Rule in Foss v Harbottle?' (1997) 2 Company Financial and Insolvency Law Review 219; B R Cheffins, 'Reforming the Derivative Action: The Canadian Experience and British Prospects' (1997) 2 Company Financial and Insolvency Law Review 227. 
shareholder can establish a case in which the action harming the company constitutes a fraud on the minority and where the wrongdoers control the company, he or she will be permitted to take derivative proceedings which are derived from the company. This trend has been followed by a number of countries in recent legislation, such as the UK, ${ }^{5}$ Australia, ${ }^{6}$ Canada, ${ }^{7}$ New Zealand ${ }^{8}$ and Singapore. ${ }^{9}$

In spite of the fact that China does not follow the rule of common law, after much consideration and public consultation, the derivative action was introduced with high expectations during a CCL reform in 2005, coming into effect on 1 January 2006. The rule, which was proposed to the Standing Committee of the National People's Congress in February 2005, was adopted to address one of 12 defects in the old CCLs. The changes regarding derivative action are part of a series of changes surrounding shareholder protection, especially for minority shareholders. The Chinese legal system is still distinguished from other jurisdictions by the underlying Chinese market and its legal institution in the context of a control-based corporate governance model. ${ }^{10}$ The new provisions for derivative action were embodied in both the CCL 2006 and the Chinese Securities Law 2006. The provisions showed both convergence and divergence characteristics when compared with statutory derivative action provision in other legislations. The reforms in the new CCL reflect a compromise in relation to the efficiency of CCL and procedure law in terms of the protection of shareholders, especially minority shareholders.

It is vital to combat the abuse of derivative action in China, a country with an emerging corporate governance model, a weak legal system and inefficient enforcement measures. This article examines several deficiencies in derivative action, with the purpose of arguing for a more effective and positive derivative action rule for the benefit of shareholders and their companies, and also for the development of CCL and the reconstruction of the Chinese corporate governance system. Corporate governance theories, namely agency theory and path dependence theory, will be discussed as theoretical arguments for a more efficient and enforceable derivative action system in China.

\section{Emerging derivative actions}

The rule in Foss $v$ Harbottle is that, in general, 'where a wrong is done to a company, only the company may sue for the damages caused to it; a shareholder has no right to bring an action on behalf of the company in order to protect the value of his shares'. ${ }^{11}$ Two principles stem from this general rule, namely the elementary principle ${ }^{12}$ and the principle of majority rule. ${ }^{13}$ A derivative claim emanates from the 'fraud on the minority' exception to the rules enshrined in Foss $v$ Harbottle, which was designed by the court to be a device to allow minority shareholders to bring a claim against those who control the company. In such a

5 See Companies Act 2006, s 236.

6 Corporations Act 2001, pt 2F.1A

7 See Canadian Business Corporations Act 1985, ss 232 and 242.

8 See Companies Act 1993 (NZ), ss 165 and 166; see also P Prince, 'Australia's Derivative Action: Using the New Zealand Experience' (2000) 18 Company and Securities Law Journal 493; S Watson, 'A Matter of Balance: The Statutory Derivative Action in New Zealand' (1998) 19 Company Lawyer 236.

9 Companies Act 1994 (Singapore), cap 50, s 216.

10 X Huang, 'Derivative Action in China: Law and Practice' (2010) 6 Cambridge Student Law Review 246, 246-47; see also J Zhao and S Wen, 'Promoting Stakeholders' Interests in the Unique Chinese Corporate Governance Model: More Socially Responsible Corporations?’ (2010) 21 International Company and Commercial Law Review 373.

11 Newbriggin-by-the-Sea Gas Co. Ltd v Armstrong (1879) 13 Ch D 310.

12 Konamaneni v Rolls-Royce Industrial [2002] 1 BCLC 336.

13 Carlen v Drury (1812) 1 Ves \& Bea 149. 
legal claim, the minority shareholders, instead of enforcing a right that belongs to them, are vested in and therefore derived from the company ${ }^{14}$ and are therefore in the representative capacity of the company. ${ }^{15}$ In the UK, the new statutory derivative action, as provided in ss 260-64 of the Companies Act 2006, is built on principles developed by the courts over the last 150 years. With regard to civil law countries, in Germany, for instance, AktG, the legislative framework governing derivative claims for public limited companies, was set out in s 148 of the German Aktiengesetz introduced by art $1 \mathrm{nr} 15$ of the Act on Corporate Integrity and Modernisation of the Right of Avoidance (Gesetz zui Unternehmensintegritat und Moderniserung des Anfechtungsrechts, UMAG). ${ }^{16}$

The emergence of derivative action in China is the result of the rapid development of the stock market. Chinese stock exchanges, including the ones in Shanghai and Shenzhen, developed very quickly after 1990 and by 2008 China's stock market had grown to become the second largest in Asia after Japan. By 1 April 2013, there were 2491 listed companies with a total of capital of 38.805 trillion renminbi (RMB) ( $\left\{3.88\right.$ trillion). ${ }^{17}$ One of the interesting characteristics of the Chinese capital market is the large percentage of small investors (owning less than 1 million RMB in cash-worth of shares), accounting for 99 per cent of the total number of capital accounts. ${ }^{18}$ The average turnover rate is seven times higher than rates in more mature markets. ${ }^{19}$ In order to counter the booming capital market packed with unsophisticated individual investors, the problems of inadequate shareholder protection are becoming increasingly important for securities regulators. ${ }^{20}$ Logically, since the coming into force of Company Law 1993, the Central Committee of the Communist Party of China shifted the corporate objectives of reform in state-owned enterprises (SOEs) from power-delegating and profit-sharing to the establishment of a modern enterprise system, in the context of which company law was a significant factor. ${ }^{21}$ However, in CCL 1993 there was no explicit section allowing for derivative action on the part of shareholders. Article 111, the only provision referring to shareholders' action in CCL 1993, gave shareholders legitimate rights of action but failed to indicate whether derivative action would be permitted. Claimants in a derivative claim can sue based on the corporate right of action, and the right provided in art 111 of CCL 1993 was a typical direct action, rather than being derived from the rights of the company. No substantial or procedural rules have been provided in art 111 for derivative claims to make the claim fundamentally different from shareholders' personal actions, and therefore the article cannot be regarded as a legal basis for derivative action in China. 22

Legislative interpretation completed the positive position of derivative action when Mr Guogang Li, the deputy president of the Supreme People's Court, concluded that courts would accept derivative action in his speech to the Meeting of China's Court Adjudication

14 See Percival $v$ Wright [1902] 2 Ch 421 Ch D.

15 Cooke v Cooke [1997] 2 BCLC 28 Ch D.

16 Bgb1 I P 2802.

17 See China Securities Regulatory Commission, Statistics Data of September 2012 <www.csrc.gov.cn/ pub/zjhpublic/G00306204/zqscyb/201210/t20121017_215899.htm>.

18 See China Securities Regulatory Commission, China Capital Markets Development Report (in Chinese) (2008) 269 <www.csrc.gov.cn/pub/newsite/yjzx/cbwxz/ebook/P020090315493496092493.pdf>.

19 Ibid.

20 X Huang, 'Shareholders Revolt: The Statutory Derivative Action in China' (Comparative Research in Law and Political Economy Research Paper 49/2009) 5.

21 F X Hong and S H Goo, 'Derivative Action in China: Problems and Prospectus' [2009] Journal of Business Law 376, 377.

22 However, there is controversy about this, since it has been argued that the right to derivative action can in fact be implied elsewhere in art 14 (2) of CCL 1993 and art 63 of CCL 1993. 
Work for Civil and Commercial Affairs on 11 December 2002. The legitimate position of shareholders in bringing a derivative claim was further confirmed in 'Opinions on Some Issues in Trials for Legal Actions Related to Company Disputes (No 1)' promulgated by the Shanghai People's Court in 2003 when the system was first introduced in China. Further, 'Opinions on Some Issues in Trials for Legal Actions Applied with Company Law', promulgated by the High People's Court of JiangSu Province in 2003, and 'Opinions on Some Issues in Trials for Legal Actions Related to the Company Disputes' promulgated by the Beijing High Court one year later also stipulated the rules for shareholder derivative action. However, these judicial opinions were only for judges to use for reference, and as such they did not have legally binding effects. Due to the disparities in procedural requirements and the lack of experience and common law support, it was still very difficult for shareholders to successfully bring derivative claims.

A few cases need to be discussed here to illuminate the Chinese derivative action system pre-CCL 2006. Despite the fact that derivative action is accepted by both the local courts and wider legislation, not many suits have been brought against companies, especially publicly listed companies, either before or after the formal introduction of the system in CCL 2006. Derivative suits filed by minority shareholders declined due to the fact that there was no legal basis for derivative action. The Shanghai Intermediate People's Court refused to entertain it in Zhongtian v Bichun in 1996. The courts first acknowledged a derivative action lawsuit in the case of Zhangïagang Fibre Company in 1994, where the Supreme People's Court was asked for guidance on the question of whether a factory, a Chinese investor in a Chinese-foreign equity joint venture, was able to represent the joint venture in bringing a lawsuit against a vendor to the joint venture. The Supreme Court held that the Chinese factory could exercise the litigation right of the cooperative joint venture. Despite the fact that the case was hedged with many conditions and had limited broader applicability, this was the first specific acceptance of a derivative action where shareholders were given legitimacy to take an action to redress a wrong where a company was unable to do so. ${ }^{23}$ The response from the Supreme Court was used and cited in cases such as Zhejiang Wu Fang Zhai in 2001, and in decisions by the Guangdong Higher People's Court in Guangzhou Tianhe Scitech in 2003. However, because the judgment in the Guangdong Tianhe Scitech case was issued after 1 January 2006, CCL 2006 could have been applied although the court chose not to.

Regarding listed companies, three cases have been filed by minority shareholders, without exception due to the misappropriation of companies' capital by controlling shareholders. In the case of Mr Shao v Zhao Xinxian (000999), Mr Shao, as a minority shareholder of Sanjiu Medical and Pharmaceutical Co Ltd, filed a lawsuit on 8 April 82003 against Zhao Xinxian, the chair of Sanjiu, due to misappropriations in Sanjiu. The law suit was rejected on the grounds that 'derivative action shall be brought based on the interests of all shareholders and $\mathrm{Mr}$ Shao needs the permission of all shareholders for filing the lawsuit', which was impossible in the case of Sanjiu considering the shareholding ownership structure at the time, according to which the two largest shareholders owned more than 70 per cent of the shares and were both involved in the misappropriations. The court denied

23 See Zuigao Renmin Fayuan Guanyu Zhongwaihezi Jingying Qiye Duiwai Fasheng Jingïi Hetong Jiufen, Kongzhi He Ying Qiye De Waifang Yu Maifang You Lihai Yuanxi, Heying Qiye De Zhongfang Yingyi Sheide Mingyi Xiang Renmin Fayuan Qisu Wenti De Fuan 1994 (Reply from the Supreme People's Court on the issues in whose name shall the Chinese side of the joint venture file a lawsuit to the People's Court when a Chinese foreign equity joint venture has an external controversy over an economic contract, and the foreign side which controls the joint venture has a direct interest relationship with the seller 1994); see also D C Clarke and N C Howson, 'Pathway to Minority Shareholder Protection: Derivative Action in People's Republic of China' in D W Puchniak, H Baum and M Ewing-Chow, The Derivative Action in Asia: A Comparative and Functional Approach (CUP 2012) 243, 265. 
the enforcing effect of the Corporate Governance Code $2002^{24}$ and took a cautious attitude in the absence of litigations on derivative action. In addition to the case of Sanjiu, derivative action was accepted in another two cases with unknown subsequent developments, including Henan Lianbua Weijing (600186) ${ }^{25}$ and Shenzhen Xingdu Hotel (000033).

In order to promote the position of shareholders and improve the incomplete and unsatisfactory legislative approach in CCL, the CCL 2006 provides shareholder with cumulative voting rights, ${ }^{26}$ the right to request the companies to repurchase their shares at a reasonable price ${ }^{27}$ and the right of viewing important company documents. ${ }^{28}$ Most innovatively, the provision for statutory derivative action was introduced in art 152 of CCL 2006 as one of the key amendments introduced to enhance shareholder protection:

where a director or senior manager is under the circumstance as stated in Article 150 of the law (where a director, supervisor or senior manager violates the law, administrative regulations or the article of association during the course of performing his duty), the shareholders of the limited liability company or joint stock limited company separately or aggregately holding one per cent or more of the total shares of the company for at least 180 consecutive days before the commencement of the action may require the board of supervisors or the supervisor of a limited liability company with no board of supervisor in writing to file a lawsuit in the People's Court.

Besides this, the provision of a mechanism for shareholder derivative action can also be found in Chinese Securities Law 2005, where:

shareholder derivative actions can be brought by shareholders when directors, supervisors, senior managerial staff or shareholders holding more than five per cent or more of the company shares have breached the restriction on trading in company shares during a six-month period. ${ }^{29}$

There was an increase in the number of lawsuits brought by minority shareholders based on s 152 after the enforcement of the derivative claim action in CCL 2006. ${ }^{30}$ However, most of these lawsuits have been focused on limited liability companies, with a striking absence of actions targeted at companies limited by shares. ${ }^{31}$ As for listed companies, there has only been one lawsuit brought by shareholders and subsequently accepted by the Shandong Higher People's Court on 11 December 2009. The Sanlian Shangshe case (2009), as the first shareholder derivative lawsuit towards a listed company after the enforcement of CCL 2006, has important practical significance. However, the case is still sub judice and the filing of the case is relatively slow. Unlike classic derivative action cases, this case involves an attempt by the plaintiffs, 78 shareholders of Shanlian Shangshe, to bring a derivative

24 See Code of Corporate Governance for Listed Companies 2002, art 4.

25 For the case report see www.sse.com.cn/cs/zhs/scfw/gg/ssgs/2004-07-23/600186_20040723_1.pdf>.

26 CCL 2006, art 106.

27 CCL 2006, art 75

28 CCL 2006, art 34.

29 Chinese Securities Law 2005, art 47.

30 Y Ji and L Zhu, 'Dissuasions of Jurisdictional Issues of Shareholder Derivative Lawsuit in China (Qiantan Gudong Paisheng Susong Anjian de Guanxiaquan Wenti)' (2008) available via China Court website <http://old.chinacourt.org/html/article/200812/09/334742.shtml>; see cases such as Li Xiaozhang and Twenty other shareholders v Xiao Wuyong \& Zhang Dingzhong re: Nnanchuan Municipal Hardware Infrastructure Electric Chemical Industry Company Limited (2006); Dong Fengchang v Fang Yishu re: Shanghai Zhongjian Enterprise Company Limited (2008); Zhu Yongjun and Twenty other Shareholder Plaintiffs v Liu Huanren, Zhu Yongjun and Ma Zhonghua re: Shizuishan Municipal Autonomous Region Shiquidshan Municipal Intermediate People's Court (2009).

31 See D C Clarke and N C Howson, 'Pathway to Minority Shareholder Protection: Derivative Action in People's Republic of China' in Puchniak et al (n 23) 275-76. 
claim against the former controlling shareholder. From discussions on the reality of applications of derivative action pre- and post-CCL 2006, it is obvious that derivative action in China has been used in a very limited fashion by minority shareholders, despite extensive reports of the power abuse by controlling shareholders and directors. In the next sections, a few factors that hinder the application of the system and related proposed reform suggestions will be discussed with reference to two corporate governance theories.

\section{Factors hindering the effective enforcement of derivative action in China}

\subsection{Shareholding PerCentage AND Shareholding Period}

The locus standi requirements were imposed for shareholders who want to put forward a derivative claim in China in order to prevent unmeritorious suits. ${ }^{32}$ Based on art 2 of CCL 2006, CCL only deals with two types of company including limited liability companies (youxian zeren gongsi) and companies limited by shares (gufen youxian goungsi). A limited liability company is normally intended for a much smaller and more closely connected group of investors and they are recognised as 'private' or 'closed' companies. On the other hand, companies limited by shares are the equivalent of Delaware corporations or the German Aktiengesellschaft which may be traded on the stock exchange. Under art 152 of CCL 2006, the issues are treated differently depending on the type of company involved. In the case of limited liability companies any shareholder has standing to sue, while standing requirements are imposed for joint stock limited liability companies. There are advantages in adopting this approach to the issue of standing. It is argued that the "plight of minority shareholders in the limited liability company is generally graver than that of their counterparts in the joint stock limited liability company'.33 Shareholders in limited liability companies are in a comparatively disadvantaged position since they lack a liquid market, while shareholders in joint stock limited liability companies can choose to leave the company by selling their shares on the stock exchange market. Furthermore, the regulations issued by authorities such as the China Securities Regulatory Commission and the Shenzhen and Shanghai stock exchanges have offered joint stock limited liability companies adequate monitoring, and, as a result of this monitoring, a better corporate governance framework within these companies. ${ }^{34}$ Also, the abuse of derivative action in limited liability companies is supposedly rare. ${ }^{35}$ Therefore, the need to establish a derivative claim system to support shareholders and improve corporate governance seems greater in limited liability companies. ${ }^{36}$

There are deficiencies in the requirements for standing to sue. The 1 per cent shareholding requirement was imposed on shareholders in joint stock companies who want to bring a derivative claim, but not in limited liability companies. Based on a survey conducted by Yang in 2006 examining the shareholding ownership structure of listed companies in China with a highly concentrated shareholding ownership, the proportion of

32 The requirements, however, are not just limited to China; for discussions on requirements in the UK, see V Joffe, D Drake, G Richardson, D Lightman and T Gollingwood, Minority Shareholders: Law Practice and Procedure (4th edn, OUP 2011) ch 3.

33 H Huang, 'The Statutory Derivative Action in China: Critical Analysis and Recommendations for Reform' (2007) 4(2) Berkeley Business Law Journal 227, 237.

34 Evidence of a better corporate governance framework can be found in art 123 of CCL 2006, requiring a listed company to have independent director(s).

35 R B Thompson and R S Thompson, 'The Public and Private Faces of Derivate Lawsuits' (2004) 57 Vanderbilt Law Review 1747, 1784-85; see also X N Li, A Comparative Study of Shareholders' Derivative Action: England, the United States, Germany and China (Dordrecht: Kluwer 2007).

36 J Deng, 'Building an Investor-Friendly Shareholder Derivative Lawsuit System in China' (2005) 46 Harvard International Law Journal 347; for the relevant empirical research see Ramsay and Saunders (n 3). 
shares held by the largest shareholder is in excess of 45 per cent, the second largest is about 5 per cent, while the third is about 3 per cent. No individual shareholder held more than 1 per cent of any company's shares. ${ }^{37}$ Therefore, the chance of owning more than 1 per cent of the shares is very small for individual shareholders, apart from the top three shareholders. Besides, it has been shown that the average shareholding of one institutional shareholder of a company was approximately 1.4 per cent, ${ }^{38}$ and the data indicate that it is unlikely that individual minority shareholders will meet the entry level requirement. Furthermore, the minimum capital requirement for being a listed company is RMB 30 million according to Chinese security law ${ }^{39}$ and, therefore, shareholder(s) who want to bring a derivative law suit must individually or collectively own at least RMB 0.3 million of shares to be qualified plaintiffs of a derivative action. However, the 2011 annual report of the Shanghai Stock Exchange reveals that this is true for only 4.69 per cent of the individual investors in the Shanghai Stock Exchange. ${ }^{40}$ It is also very hard to call for a collective action for shareholders in listed companies with dispersed shareholding ownership, considering the fact that this can be a very time-consuming and expensive process with diversified opinions from different shareholders, and even a lack of knowledge about the operation of the corporation.

The percentage requirement means that the legitimate number of shareholders varies dramatically between large listed companies and comparatively smaller companies. Consequently, collective action from shareholders in bringing a claim against misbehaving directors will be much harder in large corporations. Because of this, Zhu and Chen proposed a replacement of the percentage requirement with a requirement based on the value of shares. ${ }^{41}$ Alternatively, others have suggested that a lower percentage of the shareholding in listed companies in China should be necessary in order to qualify for a derivative claim. ${ }^{42}$ In the absence of systemic restrictive procedures for derivative action in Chinese civil procedure law, a quantitative requirement should be imposed before a derivative claim to avoid an excessive amount of litigation or malicious or frivolous law suits from shareholders. Therefore, in the author's view, a requirement based on the value of the share recruitments seems more enforceable, encouraging shareholders who have standing to make a sincere claim.

Besides this, the shareholders of joint stock limited companies are required to hold their shares for at least 180 consecutive days before the action starts. ${ }^{43}$ This standing rule is designed to stop people from buying shares with the intention of bringing malicious litigation, and to prevent excessive workload for directors, supervisors and senior managers in dealing with claims. With a very immature stock market, the only aim of most Chinese shareholders is to get immediate returns from their investments through share transactions. The understanding of shareholders of the operations and management policies involved in running corporations is either very limited or non-existent. Statistics showed that the

37 J Yang, 'The Role of Shareholders in Enforcing Directors' Duties: A Comparative Study of the United Kingdom and China (Part 2)' (2006) 7 International Company and Commercial Law Review 381, 390.

38 Y Zeng and J Zhang, 'The Dark Side of Institutional Shareholder Activism in Emerging Market Evidence from China's Non-Tradable' (2011) 40 Asia-Pacific Journal of Financial Studies 240

39 China Security Law 2005, art 16.

40 Shanghai Stock Exchange, Shanghai Stock Exchange 2011 Annual Report (Shanghai Stock Exchange 2011$) 346$.

41 H C Zhu and G Q Chen, 'China Introduces Statutory Derivative Action' (2005) 24 International Financial Law Review 21, 22.

42 J H Liu, On the Shareholder's Derivative Action (Beijing: Chinese People's Public Security University Publisher 2008), ch 3.

43 Article 152 CCL 2006; see also the Supreme People's Court Regulations on the Application of Company Law of the People's Republic of China 2006. 
average shareholding period on the securities market in 2005 was less than 120 days. ${ }^{44}$ Therefore, the 180-day requirement does not appear to be practical in the unique Chinese context. Logically, it could be suggested that the shareholding period might be shortened to make the derivative claim an effective way of obtaining shareholder remedies.

The calculation of the 180-day period is also problematic. There are generally three interpretations of the term ' 180 consecutive days': (1) from the date of purchasing the shares to the date of the misconduct of the directors, supervisors or senior management; (2) from the date of purchasing the shares to the date of bringing the derivative action where the misconduct of the directors, supervisors or senior management happens after the date of purchasing the shares; or (3) from the date of purchasing the shares to the date of bringing the derivative action where the misconduct of the directors, supervisors or senior management happens before the date of purchasing the shares. In a positive light, this was interpreted by the Supreme Court in art 4 of the first section of the Supreme People's Court Regulations on the Application of Company Law of the People's Republic of China 2006. It is explained that the term ' 180 consecutive days' in art 152 of CCL 2006 refers to the period of time from the date of purchasing the shares to any date before or on which the shareholders bring the derivative action. Despite the fact that this interpretation makes the application of art 152 easier in practice, the cogency or legal force of this judicial interpretation, compared with the law adopted at the National People's Congress, is much weaker and less authoritative.

Achieving eligibility right is fundamental to making derivative action work effectively in China. In comparison with some jurisdictions, it is arguable that the rule on eligibility in China seems to be both under-inclusive and over-inclusive, since it may restrict certain meritorious claims while at the same time failing to discourage vexatious actions. ${ }^{45}$ Compared with the law in Australia and Canada, ${ }^{46}$ the eligibility requirements in China seem overly restrictive. According to the Australian Corporations Act 2001, the scope of the term eligible defendant is extremely broad and includes 'a member, former member, or person entitled to be registered as a member, of the company or of a related body corporate; or an officer or former officer of the company'. ${ }^{7}$ Past members were included because they might have been compelled to terminate their relationship with the company due to the underlying dispute, while members were included since they may have been adversely affected by the directors' misconduct. ${ }^{48}$ On the other hand, stipulations in CCL 2006 regarding eligible claimants appeared to be over-inclusive, making it hard to discourage unmeritorious claims. This is unlike the requirement of 'contemporaneous ownership of shares' in the US, under which the claimants 'must have been a shareholder or member of the corporation or association at the time of the transaction of which compliant is made or that the share or membership, if acquired thereafter, devoid by operation of law'. ${ }^{4}$ Therefore, potential shareholders who are qualified to bring a claim need to be shareholders

$44 \mathrm{X}$ Jin, Shareholding Structure and Corporate Governance in Listed Companies in China (Beijing: China Finance Press 2005), 143-44.

45 Huang (n 33) 242.

46 See Canada Business Corporations Act, RSC 1985, ss 238-39.

47 Australian Corporations Act 2001, s 236(1)a(i) and (ii).

48 Corporate Law Economic Reform Program Bill, HR 71, 105th Congress. Explanatory Memorandum, paras 6.26-28 (1998) <www.comlaw.gov.au/Details/C2004B00269/Explanatory\%20Memorandum/Text>.

49 Federal Rules of Civil Procedure, r 23.1. 
at the commencement of the suit and during the pendency of the suit. ${ }^{50}$ This requirement in US law is designed to 'prevent what has been considered an evil, namely, the purchasing of shares in order to maintain a derivative action designed to attach a transaction which occurred prior to the purchase of the stock'. ${ }^{51}$ Conversely, under CCL 2006, unjustifiable shareholders are able to bring claims by acquiring shares after finding a potential opportunity for bringing derivative action. Neither under-inclusive nor over-inclusive requirements for eligibility of defendants will create a healthy and workable environment for a better enforcement of CCL 2006, at least as far as the provisions on derivative actions are concerned.

\subsection{SCOPE OF DERIVATIVE ACTION STANDING}

The range of reasons that shareholders can use to bring derivative actions seems very broad based on stipulations in CCL 2006, which may include any violations of 'laws, administrative regulations or the articles of association during the course of performing his duties'. Therefore, the shareholders will be able to challenge any breach of the duties by directors according to law, regulations or articles of association. These may include breaches of fiduciary duties or duty of diligence with broad scope in the new CCL. ${ }^{52}$ Article 5 of CCL 2006 states that 'a company must, when engaging in business activities, abide by the laws and administrative regulations, observe social morals and business ethics, be in integrity and good faith, accept regulation of the government and the public, and undertake social responsibilities'. Comparatively modern terms such as 'business ethics' and 'social responsibilities' are introduced in the general provisions of CCL for the first time. It is implied in art 5 that apart from the interests of shareholders, employees and other stakeholders, the performance and activities of the company have a deep impact on the market's economic rules and public social interests. Therefore, when company directors and supervisors pursue company interests for their shareholders, they have to be socially responsible and responsible to internal and external stakeholders. ${ }^{53} \mathrm{As}$ far as legislative tenets are concerned, it is stipulated in art 1 of CCL 2006 that this legislation is enacted in order to 'standardise the organisation and activities of companies, to protect the legitimate rights and interests of companies, shareholders and creditors, to maintain socio-economic order and to promote the development of the socialist market economy'. ${ }^{4}$ However, these socially related responsibilities and legislative tendencies in protecting creditors' interests were first introduced as a guidance principle for future detailed stipulations regarding directors' duties, such as their detailed responsibilities towards various stakeholders, their duties towards stakeholders in realising these responsibilities, and the liability of corporations and directors if they are in breach of these duties. Directors' duties relating to the social aspects required

50 See West v West 126 FRD 82 (ND Ga 1992); Compare Brown v Ferro Corp 763 F2d 798 (6th Cir) cert denied 474 US 947 (11985); Rothenberg v Utd Brands Co 574 F2d 1295 (2d Cir 1997); deHaas v Empire Petroleum Co 300 F Supp 834 (1969) \& 435 F2d 1223 (10 Cir 1997); Dracbman v Harvey 435 F2d 722 (2d Cir 1971) modified en banc 453 F2d 736 (1972).

51 Rosenthal v Burry Biscuit Corp 60 A 2d 106, 111 (Del Ch 1948) see also Anadarko Petroleum Corp v Panhandle Eastern Corp 545 A.2d 1171 (Del 1988); Haff v Kerkorian 324 A 2d 215 (Del Ch 1974) affd in part, revd in part 347 A 2d 133 (Del 1975); see also C Ferrara, K T Abikoff and L L Gansler, Shareholder Derivative Litigation: Besieging the Board (New York: Law Journal Press 2013) ss 4.01-02.

52 CCL 2006, arts 148 and 149.

$53 \mathrm{~J}$ Zhao, 'The Regulation and Steering of Corporate Social Responsibility in China: Stories after the Enforcement of Chinese Company Law' (2011) 32 International Commercial and Company Law Review 400; see also J Zhao, 'The Harmonious Society, Corporate Social Responsibility and Legal Responses to Ethical Norms in Chinese Company Law' (2012) 12 Journal of Corporate Law Studies 163; J Zhao, Corporate Social Responsibility in Contemporary China (Cheltenham: Edward Elgar Publishing, forthcoming).

54 CCL 2006, art 1. 
in CCL 2006 are immature, unclear and extremely difficult to enforce. ${ }^{55}$ It is overly demanding for directors to enforce these duties in accordance with the legislative principles, and the danger of being held liable for negligence of these responsibilities could be an onerous burden for directors and deter them from taking risky decisions.

Furthermore, the duty of diligence and duty of loyalty have been introduced into CCL. Directors might be held responsible for breaching these duties simply by making bad business decisions and these onerous burdens will have a negative impact on directors when they are trying to make risky management decisions for the long-term interests of corporations. If shareholders are allowed to bring a claim against directors based on infringements of such unclear duties, this may lead to a large number of malicious suits. To counter this defect, efforts should be made to make these provisions regarding directors' duties more accessible and easy to understand for directors, especially those in small and medium-sized businesses. The improvement can be achieved by various measures, including clearer interpretations, broader enrichment with systematic codification of relevant legislation on directors' duties, and more judicial regulations and explanations from the People's Supreme Court. Also, in terms of the enforcement of directors' duties for more socially responsible corporations, establishing a sound corporate governance model with a clearer corporate objective is critical for the efficient and sustainable performance of Chinese companies.

It is also recommended that Chinese courts should adopt the concept of the business judgment rule, which was designed in the US to 'stimulate risk taking, innovation and other creative entrepreneurial activities 56 with the purpose of striking a good 'balance between the need to ensure that directors comply with the duty of diligence and the need to allow directors to take certain risks in the exercise of their discretion, ${ }^{57}$ The business judgment rule was introduced more than 180 years ago as a common law standard. ${ }^{58}$ It has been regarded as the principle that directors can employ to shield their decisions from judicial scrutiny. ${ }^{59}$ The most distinctive contribution of the business judgment rule is that it prevents the judiciary from meddling in managerial decisions. ${ }^{60}$ In this sense, the rule may be helpful in protecting directors from personal liability for claims made against them because of errors of judgment or wrong business decisions, protecting them against shareholders' derivative

55 L W Lin, 'Corporate Social Responsibility in China: Window Dressing or Structural Change' (2010) 28 Berkeley Journal of International Law 64.

56 See s 4.01 of American Law Institute, Principles of Corporate Governance: An Analysis and Recommendations (Proposed Final Draft, ALI 1992); see also J E Kerr, 'Sustainability Meets Profitability: The Convenient Truth of How the Business Judgment Rule Protects a Board's Decision to Engage in Social Entrepreneurship' (2007) 29 Cardozo Law Review 623; C X Weng, 'Assessing the Applicability of the Business Judgment Rule and the "Defensive" Business Judgment Rule in the Chinese Judiciary: A Perspective on Takeover Dispute Adjudication' (2010) 34 Fordham International Law Journal 124; R Sprague and A J Lyttle, 'Shareholder Primacy and the Business Judgment Rule: Arguments for Expanded Corporate Democracy' (2010) 16 Stanford Journal of Law, Business and Finance 1; see also Percy v Millaudon (1829) 8 Mart (ns) 68; Revlon Inc v MacAndrews \& Forbes Holdings Inc (1986) 506 A2d 173 and more recently cases like Gantler v Stephens (Del 2009) 965 A2d 695.

57 F Ma, 'The Deficiency of Derivative Action in China' (2010) 31 Company Lawyer 150, 153; see also D M Branson, 'A Business Judgment Rule for Incorporating Jurisdictions in Asia' (2011) 23 Singapore Academy of Law Journal 687; J H Farrar, 'Directors' Duties of Care: Issues of Classification, Solvency and Business Judgment and Dangers of Legal Transplant' (2011) 23 Singapore Academy of Law Journal 745.

58 See S S Arusht, 'The Business Judgment Rule Revisited' (1979) 8 Hofstra Law Review 93, 93.

59 See J Hinsey, 'Business Judgment and the American Law Institute's Corporate Governance Project: The Rule, the Doctrine and the Reality' (1985) 52 George Washington Law Review 609, 610.

60 C X Weng, 'Assessing the Applicability of the Business Judgment Rule and the Defensive Business Judgment Rule in the Chinese' (2010) 34 Fordham International Law Journal 124. 
actions based on their negligence. ${ }^{61}$ Both academics and practitioners in China have realised the importance of the concept of business judgment, and it is suggested that Chinese judges should reference the principle in managing their discretions when they judge whether directors are in breach of the duties imposed in CCL 2006. ${ }^{62}$

\subsection{Funding Derivative ACTIONS IN CHINA AND INCentives FOR ChINeSE SHAREHOLDERS TO BRING ACTIONS}

The cost of litigation has always been a key issue in derivative action, since the related rules will have a direct impact on the popularity of the suit. Private shareholder actions have been regarded as a major feature of corporate governance in the US, but this is not the case in the UK because of the fact that the rule on litigation costs promotes the launching of law suits in the US but discourages the same in the UK. ${ }^{63}$ The different treatment of litigation fees can group the jurisdictions adopting derivative claims into three streams. In the US, it is the litigant's responsibility to fund their litigation expenses without considering the results of the litigation, while the attorney's fees are contingent only on successfully litigated or settled cases. ${ }^{64}$ The traditional regime adopted in the UK is the 'loser pays' regime, where fees are typically assessed against the loser on 'a standard basis' which covers litigation costs 'proportionately and reasonably incurred and proportionate and reasonable in amount'. ${ }^{65}$ However, conditional fee arrangements were introduced in England as a result of the reform of civil litigation funding. ${ }^{66}$ In this context, shareholders who want to bring derivative claims could adopt 'no win no fee' arrangements with their lawyers. Thirdly, in Japan, the derivative claim cost is fixed at 8200 Japanese yen, by deeming derivative actions to be non-property claims. ${ }^{67}$ This followed a new interpretation given by the Tokyo High Court on 30 May 1993.68

It is argued that current Chinese law and regulations on both civil litigation filing fees and attorneys' fees effectively deter shareholders from bringing derivative claims on behalf of corporations. ${ }^{69}$ As far as filing fees are concerned, the rule on these fees is regulated by the Measure on Payment of Litigation (Susong Fei Jiaona Banfa) 2007. According to art 29 of

61 M B Hemraj, 'The Business Judgment Rule in Corporate Law' (2004) 5 International Company and Commercial Law Review 192, 198.

62 F Deng, 'A Legal Analysis of Leadership Accountability: An Approach from the Director's Duty of Care in Corporate Law' (2007) 28 Social Science in China 3.

63 J Armour, B Black, B Cheffins and R Nolan, Private Enforcement of Corporate Law: An Eremitical Comparison of the US and UK (Preliminary Draft of Law and Economic Working Paper No 89, University of Texas School of Law 2007).

64 Alyeska Pipeline Service Co v Wilderness Society 421 US 240 (1975); Hall v Cole 412 US 1 (1974); Mills v Electric AutoLite Co 396 US 375 (1970); Duban v Diversfied Mortgage Investors 87 FRD 33 (SD NY 1980); see also D A DeMott, Shareholder Derivative Action: Law and Practice (Thompson 2003) s 6.12.

65 CPR 1998, SI 1998/3132, 44.5; Lownds v Home Office [2002] 1 WLR 2450, 2453.

66 J Peynser, 'A Revolution by Degrees: From Costs to Financing and the End of the Indemnity Principle' [2001] Web Journal of Current Legal Issues; see also A Hogan, 'Conditional Fees: Problems Solved and Problems Yet to Come’ (2006) 1 Journal of Personal Injury Law 40.

67 Commercial Code of Japan 1993, art 267(4).

68 See Asai v Iwasaki (or Nikko Securities case) Tokyo District Court, 101 Shiryoban Shoji Homu 37, revd, Judgment of 30 March 1993, 109 Shiryoban Shoji Homu 70. It is worth mentioning that this interpretation of the old code provision was confirmed by the Supreme Court on 10 October 2002; see T Fujita, 'Transformation of the Management Liability Regime in Japan in the Wake of the 1993 Revision' in H Kanda, K S Kim and C J Milhaupt (eds), Transforming Corporate Governance in East Asia (Routledge 2008) 15, 17.

69 F P Meng, 'Funding Derivative Action in China: Lessons from Wallersteiner v Moir (No 2) for the Court' (2010) 31 Company Lawyer 29, 29; see also Z Zhang, 'Making Shareholder Derivative Action Happen in China: How Should Lawsuits be Funded' (2010) 40 Hong Kong Law Journal 523. 
the Measure, a major part of the fee the litigation bears is the case acceptance fee, which is based on the loser pays rule. Similar to the litigation calculation rules adopted in Japan before the 1993 Commercial Code, a sliding scale system is adopted. This means that the litigation fee is charged in proportion to the amount of damage the defendants seek to claim. According to art 13 (1) of the Measure, RMB 50 is charged for damages of no more than RMB 10,000. After this fixed amount, different percentages of the damages sought will be charged for different damage amounts. However, the sliding-scale system has been historically proven to be a barrier to shareholder derivative claims in Japan. ${ }^{70}$ The actual effect of the pre-1993 Japanese litigation fee principles was to discourage all suits due to the high litigation fees, which are not recoverable unless the shareholder eventually wins the case. ${ }^{71}$ Statistics show that there were less than 20 derivative action suits between 1950 and 1990, but there was a dramatic increase after 1993 to hundreds of law suits each year. ${ }^{72}$ Therefore, in the author's opinion, a reform should also be adopted in China to fix the charge of the litigation cost, since the amount of damages to be paid to the suing shareholder is normally difficult to determine. Therefore, a relatively lower fee of RMB 1000 Yuan (equivalent to 8200 yen) should be charged.

As for the lawyers' fees, two options are available according to the Measures for the Administration of Attorneys' Fees 2006: the 'contingency fee arrangement', where the fees are fixed at a percentage no higher than 30 per cent of the amount of the damages claimed as the result of a successful litigation; ${ }^{73}$ and the 'reasonable fee arrangement', where the fees are charged on the basis of the subject-matter of the case or of the time taken. ${ }^{74}$ However, neither arrangement seems fair or reasonable for shareholders, or gives them sufficient incentive to bring a derivative action. If the litigation is successful, the benefits awarded accrue to the company. The defendant shareholder would have to personally fund the lawyer's fee because of the service contract between the lawyer and the shareholder. Under the contingency fee arrangement, the shareholder would be personally liable for up to 30 per cent of the damages recovered if the litigation is successful. Paradoxically, if the litigation is not successful, the shareholder might be in a better position because of being free from responsibility for the lawyer's fee.

A more sensible fee arrangement ${ }^{75}$ is important for a more enforceable derivative claim system and better corporate governance in China. The author agrees with the indemnity order' enforced in the UK, ${ }^{76}$ which was first made legitimate in Wallersteiner v Moir (No 2) ${ }^{77}$ where Lord Denning asserted that a company should indemnify a shareholder defendant in a derivative suit since the shareholder acts on behalf of the company and the company is the direct beneficiary. The shareholders who bring the claim should be treated as trustees or agents who act on behalf of the beneficiary or the principal. Lord Denning suggested a more reasonable procedural rule when Mr Moir's plight found sympathy with the Court of Appeal:

70 M Blomstrom and S La Croix, Institutional Change in Japan (Routledge 2006) 241; see also M West, 'The Pricing of Shareholder Derivative Action in Japan and United States' (1994) 88 Northwestern University Law Review 1436.

71 C J Milhaupt and M D West, Economic Organizations and Corporate Governance in Japan: The Impact of Formal and Informal Rule (OUP 2004) 21.

72 M D West, 'Why Shareholders Sue: The Evidence from Japan' (2001) 30 Journal of Legal Studies 351, 352.

73 Measures for the Administration of Attorneys' Fee 2006, arts 11-13.

74 Ibid art 10.

75 Meng (n 69) 29-30.

76 Ibid 29.

77 Wallersteiner v Moir (No 2) [1975] QB 373; see also Masri v Consolidated Contractors International Co SAL [2011] EWHC 1024; Air Canada v Secretly of State for Trade (No 2) [1983] WLR 494. 
The minority shareholder should apply ex parte to the master for directions, supported by an opinion of counsel as to whether there is a reasonable case or not. The master may then, if he thinks fit, straightaway approve the continuance of the proceeding until close of pleadings, or until after discovery or until trial ... The master need not, however, decide it ex parte . . The master should simply ask himself: is there a reasonable case for the minority shareholder to bring at the expense (eventually) of the company? If there is, let's go ahead. ${ }^{78}$

It is normally non-arguable that, even if the derivative action is successful, the recoveries accrue to the company as a whole with the shareholder who brought the claim receiving only a small percentage of the benefit. The fact that other shareholders may have a 'free ride' and directly benefit from derivative claims brought by the defendant shareholder, who did all the hard work, will make defendant shareholders less willing and give them less incentive to bring such actions in the future.

\section{Corporate governance theory and the establishment of a more efficient derivative action scheme in China}

Effective from 2006, the derivative claim action system embedded in CCL was designed to improve the Chinese corporate governance system and provide a weapon against insider and controlling shareholder abuse in newly corporatised listed companies in China. ${ }^{79}$ Since the enforcement of CCL 2006, the demand for minority shareholder protection has increased as the result of demand from several directions. With the increasing number of dividable shareholders, largely due to the expansion of the securities market, the rights and liabilities of investors are promoted by the public media in the aftermath of corporate scandals and market turbulence. ${ }^{80}$ The focus on the development of the stock market in order to ease the pressures on loan capital from banking finance is making shareholders' rights and remedies increasingly important.

The conversion of SOEs enables the government to be less concerned about providing guidance and privileges to SOEs, and by extension the state as the biggest shareholder in SOEs. ${ }^{81}$ China has experienced an unprecedented wave of corporatisation and privatisation since implementing CCL 1993.82 The corporatisation of business organisations with decreased government interference under CCL 2006, in comparison with CCL 1993, means that corporate governance theory is closely related to the protection of the shareholder in China.

Systematic corporate governance reform is becoming increasingly important in the emerging Chinese market, which is moving towards a more free-market system. ${ }^{83}$ Shareholder derivative claims are always used as a 'case study' for the relationship between

78 Wallersteiner v Moir (No 2) [1975] QB 373 AT 392.

79 D C Clark and N C Howson, 'Pathway to Minority Shareholder Protection: Derivative Action in the People's Republic of China' in D Puchniak, H Baum and M Ewing-Chow (eds), The Derivative Action in Asia: A Comparative and Functional Approach ( CUP 2012) ch 6, 1.

80 X Tang, 'Protecting Minority Shareholders in China: A Task for Both Legislations and Enforcement', ch 9 in Kanda et al (n 69).

81 Ibid.

82 Y Wei, 'The Development of Securities Market and Regulations in China' (2005) 27 Loyola of Los Angeles International and Comparative Law Review 479.

83 S C Jain, Emerging Economies and the Transformation of International Business (Cheltenham: Edward Elgar Publishing 2006) 383-86. 
institutions and the norms of corporate governance. ${ }^{84}$ Chinese government officials and commentators believe that shareholder derivative claim actions will promote better corporate governance in China, ${ }^{85}$ and it is an 'almost unanimous understanding' that China has to institute a system for shareholder derivative suits. ${ }^{86}$ Conversely, however, corporate governance theories could be adopted as an effective way of illuminating an improved institutionalised derivative claim system. The lack of a shareholder remedy contributed to the inefficient corporate governance system in China, especially for minority shareholders. ${ }^{87}$ Proponents of derivative action describe it as 'the chief regulator of corporate management'. ${ }^{88}$ It plays a significant role in deterring managerial misconduct, and thereby reduces the agency cost inherent in corporate management. ${ }^{89}$ It is predicted that the adoption of the actions will be 'a major development of Chinese company legislations' with 'far reaching implication for corporate governance'. ${ }^{90}$ However, the effectiveness of transplanting the derivative action rule into China may not always lead to the intended consequences and results.

Corporate governance theories, including agency theory and path dependence theory, can help to explain the Chinese derivation action with unique 'Chinese characteristics'. China's economy is in a critical transitional phase with changes in the enterprise system and the securities market. This places the Chinese corporate governance system in a unique position to adopt the derivative action rule. The company law system in China, including civil procedural law, economic transformation, current legal enforcement problems, qualification of practitioners and judges, and Chinese traditions and history, will have to be considered collectively with the corporate governance system to determine the effectiveness of adopting a derivative action system.

'The judiciary is weak, unsophisticated and riddled with corruption' in China. ${ }^{91}$ Furthermore, Chinese judges are often criticised for their inadequate qualifications, poor training and lack of knowledge and skills. The reputation and authority of the judiciary has been negatively compromised as a result of corruption and political interference in judicial processes. Guanxi and renqing make the supervisory board, which does not have power over the managerial board and has no remit to elect or dismiss managerial directors, even less efficient (guanxi - close personal relationships or connections, which are established connections to secure benefits - and renqing - getting benefits or advantages from a relationship - are major elements in Chinese commercial life). Institutional shareholders

84 See examples such as: D C Clark, The Ecology of Corporate Governance in China (George Washington University Law and Legal Theory Working Paper No 433 2008); A Keay, 'The Ultimate Objective of the Public Company and the Enforcement of the Entity Maximisation and Sustainability Model' (2010) 10 Journal of Corporate Law Studies 369; S P Ferris, T Jandik, R M Lawless and A Makhija, 'Derivative Lawsuits as a Corporate Governance Mechanism: Empirical Evidence on Board Changes Surrounding Filings' (2009) 42 Journal of Financial and Quantitative Analysis 143; A S Ginevri, 'The Rise of Long-Term Minority Shareholders' Rights in Publicly Held Corporations and Its Effect on Corporate Governance' (2011) 12 European Business Organization Law Review 587.

85 Deng (n 36) 349.

86 G Yu, 'Using Western Law to Improve China's State Owned Enterprise: Of Takeover and Securities Fraud' (2004) 39(2) Valparaiso University Law Review 339, 340.

87 G Yu, 'Towards an Institutional Competition Model of Comparative Corporate Governance Studies'(2003) 6 Journal of Chinese and Comparative Law 31, 56.

88 Cohen v Beneficial industrial Corp 337 US 541 (1949) 548.

$89 \mathrm{~J}$ Coffee and D Schwartz, 'The Survival of the Derivative Suit: An Evaluation and a Proposal for Legislative Reform' (1981) 81 Columbia Law Review 261.

90 Huang (n 33) 242.

91 Z Zhang, 'The Shareholder Derivative Action and Good Corporate Governance in China: Why the Excitement is Actually for Nothing' (2011) 28(2) UCLA Pacific Basin Law Journal 174, 175. 
and other non-controlling shareholders in China, who may be able to bring such actions, will normally be reluctant to do so because of Guanxi and renqing due to the controlling shareholders and management. These factors make the introduction of path dependence theory necessary as a theoretical base for the unique problems of establishing and enforcing an efficient derivative action system in China.

The Chinese corporate governance system is a control-based model, in which the controlling shareholders 'tightly control the list companies through concentrated ownership [and] management friendly boards. ${ }^{92}$ If derivative action is to play any role, the question is what, if any, are the net benefits of these actions for companies, shareholders and stakeholders from a social or economic perspective. It is important to introduce agency theory to the discussions of Chinese shareholding structure and the problems of derivative action in order to make this legal scheme more enforceable and popular, especially for public companies, and reduce the agency cost. With the unique characteristics of Chinese SOEs and the close guanxi between government and corporations, derivative claims are a reasonable remedy and provide an alternative way of protecting the interests of shareholders, particularly minority shareholders.

There is a strong need for China to adopt a workable derivative action system due to the current context of rapid economic transformation, as well as a high incidence of directors and majority members harming the interests of the company or the minority shareholders. In the following section, corporate governance theories will be used to discuss the possible ways of enabling legislators and regulators to make derivative action rules accessible, enforceable and efficient for Chinese investors within the unique Chinese system.

\subsection{AGENCY THEORY}

Derivative claims by shareholders are closely related to the question of control of the corporate form, and of the steps being taken on behalf of shareholders to redress the imbalance in modern corporations between the control exercised by directors and that exercised by shareholders. ${ }^{93}$ It is argued that derivative actions generate agency costs, and the risk and fear of being sued might hinder corporate directors from accepting the position in the first place. ${ }^{94}$ On the other hand, derivative actions can reduce agency cost as the claims work to 'deter mismanagement by imposing the threat of liability and therefore align the interests of managers and shareholders'. ${ }^{95}$ The adoption of the derivative claim principle will increase the costs that companies have to incur in order to attract good directors. A manager's net return from his job must equal some 'reservation' level for him to be willing to work for the company based on market forces. 96

However, it is necessary to expand the scope of shareholder remedies towards a derivative action system because of the difficulty of winning a proxy fight by getting sufficient numbers of shareholders at the requisite meeting, regardless of the fact that

92 Q Liu, 'Corporate Governance in China: Current Practices, Economic Effects and Institutional Determinants' (2006) 52 CESifo Economic Studies 415, 429.

93 D McDonough, 'Proposed New Statutory Derivative Action: Does it Go Far Enough' (1996) 8 Bond Law Review 47.

94 R R Kraakman, P Davies, H Hansmann, G Hertig, K J Hopt, H Kanda and E B Rock (eds), The Anatomy of Corporate Law: A Comparative and Functional Approach (OUP 2004) s 2.2.1.

95 I Ramsay 'Corporate Governance, Shareholder Litigation and the Prospects for a Statutory Derivative Action' (1992) 15 University of New South Wales Law Journal 149, 152.

96 A Reisberg, Derivative Actions and Corporate Governance Theory and Operation (OUP 2007) 48. 
shareholders have their own contractual remedies which manifest themselves in positive control. ${ }^{97}$ Under these circumstances, shareholders must revert to negative legal control measures to redress the imbalance in control between the owner and directors of the company, in order to obtain a balance of control and accountability. ${ }^{98}$ Due to the fact that shareholders are liable to suffer the consequences of any wrong-doing carried out by the directors in their name, they should be authorised to issue any type of instructions to the directors concerning the performance of their duties. ${ }^{99}$

Different mechanisms and principles established with the purpose of reducing agency cost problems are adopted in different legal systems. ${ }^{100}$ In China, the very high concentration of ownership is directly linked to control from the board of directors, which is regarded as a critical connection between ownership and control in the current Chinese corporate governance scheme. ${ }^{101}$ Efforts have been made by the government to reduce the over-concentration of state shareholding. Notwithstanding a general objective to create a more dispersed and competitive shareholding structure, corporatisation and ownership diversification have also led to the emergence of new owners such as individual minority shareholders, institutional investors and employee shareholders. ${ }^{102}$ However, state ownership still prevails in most listed enterprises where the state still holds a high percentage of ownership. ${ }^{103}$ These unique characteristics of Chinese corporate governance make derivative action a particularly important remedy for minority shareholders because of the difficulties of removing the directors or bringing about other changes.

Chinese corporate governance is at a primitive stage, and serious misbehaviour on the part of the board of directors is the major problem. ${ }^{104}$ Deterrence by way of legal sanction is the solution, since voluntary market discipline would not function as efficiently in China as in countries with a mature market economy. 105 Therefore, minority shareholders in China are forced to rely on negative control through legal litigation as opposed to positive control by voluntary measures. If this negative control can be used efficiently by shareholders, it will have a positive effect in enhancing managerial efficiency and accountability.

No shareholder wants to be liable for uncertain or very high costs but receive only a pro rata share of the gains from success, while other shareholders free-ride on his or her efforts. In order to enable shareholders to use negative control to its fullest extent, reasonable ligation costs are one of the key requirements. It is claimed that the effectiveness of shareholder litigation as a governance mechanism is hampered by collective action

97 UK Companies Act 2006, s 168.

98 Ramsay (n 95) 16.

99 A Carver, 'Corporate Governance: Capitalism's Fellow Traveler' in F M Patfield (ed), Perspectives on Company Law vol 2 (Dordrecht: Kluwer 1997) 69, 74-75.

100 See E Glaeser and A Shlefier, 'The Rise of the Regulatory State' (2003) 61 Journal of Economic Literature 401.

101 L H Tan and J Y Wang, 'Modeling an Efficient Corporate Governance System for China's Listed State-Owned Enterprises: Issues and Challenges in a Transitional Economy' (2007) 7 Journal of Corporate Law Studies 143, 147.

102 S Tenev, C Zhang and L Brefort, Corporate Governance and Enterprise Reform in China: Building the Institutions of Modern Market (World Bank and the International Finance Corporation 2002) 2-3.

103 S Vob and Y W Xia, 'Corporate Governance of Listed Companies in China' (Paper presented at Track 8 of IFSAM VIIIth World Congress 2006, hosted by VHB, Berlin, Germany, September 2006) 110-16<www.ctwcongress.de/ifsam/download/track_8/pap00750.pdf $>$.

$104 \mathrm{~J}$ Zhao, 'The Regulation and Steering of Corporate Social Responsibility in China: Stories after the Enforcement of Chinese Company Law' (2011) 22 International Commercial and Company Law Review 400.

105 Z Zhang, 'Legal Deterrence: The Foundation of Corporate Governance: Evidence from China' (2007) 15 Corporate Governance: An International Review 741. 
problems, because the cost of bringing a lawsuit, although less than the shareholders' aggregate gain, is typically greater than a shareholder's pro rata benefit as a claimant. ${ }^{106}$ The problem of financial incentives to police management raises a principal-agent problem; the attorney's incentives need not coincide with the shareholders' interests. As far as litigation cost is concerned, fixed litigation fees will encourage shareholders to sue on behalf of the company in order to reduce the agency cost. The fixed fee will also help to reduce monitoring costs incurred by shareholders since, in the case of derivative action, shareholder coordination is not necessary and fixed litigation fees will make the shareholders' decision easier even without any coordination. It seems reasonable that 'the availability of this action economizes on costs that otherwise would be necessarily incurred if shareholders were required to take collective action'. 107

Corporate governance is a process, a monitoring device and a mechanism to minimise problems that may be brought about in the agent-principal-third-party relationship. However, in a derivative claim, a new agent-principal-third-party relationship can be observed. The shareholder who brings the claim replaces the directors as the agent of the company as the principal, acting in the collective interests of all the shareholders. If the shareholder who brings the action, the agent in the new agency relationship, brings a derivative action on behalf of the company which is the direct beneficiary, the company is logically required to indemnify the cost of the claim simply because the litigation is brought for the company in the name of the shareholder, as is the case in a disclosed agency relationship. It is the general rule that, where a person contracts as an agent for a principal, the contract is the contract of the principal, not of the agent.

In China, the minority shareholder's right and incentive to bring action on behalf of the company becomes more important because of the shareholding ownership structure and guanxi between directors and minority shareholders. A reasonable and encouraging cost system is important for a more accessible derivative action system. Agency theory can be used as a theoretical support for a more sensible fee arrangement, including fixed litigation costs and the adoption of indemnity orders.

\subsection{PATH DEPENDENCE THEORY}

Path dependence, a comparatively new theory originating in the 1980s, suggests that an outcome or decision is shaped in specific and systematic ways by the historical path leading to it, as well as by other factors within the socio-economic context. ${ }^{108}$ While convergence theorists predict that countries, especially countries with weak legal systems, will adopt certain legal rules that have been demonstrably efficient in other jurisdictions, theorists who adhere to path dependence normally argue that divergence will still exist because legal rules are shaped by pre-existing political and social forces. ${ }^{109}$ As part of the domestic legal and financial framework, a corporate law system has significant sources of path dependence, which include historical accidents as well as economic and political particulars of the

106 R Romano, 'The Shareholder Suit: Litigation Without Foundation?’ (1991) 7 Journal of Law Economics and Organization 55, 55.

107 A Reisberg, Derivative Actions and Corporate Governance Theory and Operation (OUP 2007) 24.

108 O A Hathaway, 'The Course and Pattern of Legal Change in a Common Law System' (2001) 88 Iowa Law Review 101, 103-04.

109 K Pistor, Patterns of Legal Changes: Shareholder and Creditor Rights in Transition Economies (European Bank for Reconstruction and Development Working Paper 49 2000). 
domestic system. ${ }^{110}$ The persistence of these sources significantly contributes to the stability of the domestic corporate governance system in any local socio-economic environment.

Path dependence theory can be regarded as a theoretical base for the adoption of a derivative action system with many unique characteristics shaping a particular nation's unique corporate governance model, corporate law background, enforcement process, shareholder structure, civil procedure law, and stage of economic development. It has been argued by Bebchuk and Roe that the initial ownership structure in a country will directly influence the subsequent development of ownership structure and laws. ${ }^{111}$ Furthermore, these authors developed the theory to suggest that the interested parties possessing the power to influence ownership structure and corporate law will have both the incentive and the power to impede changes that might improve efficiency but are contrary to their private control interests. 112

In China, the term 'listed company' normally refers to listed SOEs, and the largest shareholder normally refers to the state, which dominates the shareholding in Chinese listed companies. The very high concentration of state ownership is directly linked to control from the board of directors, whose members are regarded as a critical link between ownership and control in the current Chinese corporate governance scheme. ${ }^{113}$ However, when the SOEs are listed, the local office of the Bureau of State Asset Management or its local subsidiaries always act as the largest shareholders, and the chair of the board of directors is usually a representative from the Bureau who will consult with the board and nominate the directors of the SOEs. ${ }^{114}$ Therefore, the decisions made by the board will be closely focused on the largest shareholder's interests. This unique shareholding structure makes derivative lawsuits from minority shareholders particularly valuable while the prevalence of SOEs and the concentrated ownership structure renders minority shareholders extremely vulnerable.

Furthermore, the legal environment for the protection of minority shareholders is important in determining the strength of a country's capital markets. ${ }^{115}$ The stock market in China is under-developed and market forces are very weak. ${ }^{116}$ The reason for most shareholder investment in China is to gain immediate profits from dividends. Minority shareholders are always ignorant of company performance and information disclosed, and they own stock for a relatively short shareholding period.

The arguments concerning modifications of the standing requirement in joint stock limited companies seem to be reasonable and consistent with the Chinese corporate governance framework. The unique shareholding structure and the dominant position of directors and controlling shareholders make it necessary to adapt current company law to offer efficient remedies to minority shareholders and ensure effective supervision of directors. The speculative business virtue of minority shareholders' investment and their

110 L Bebchuk and M J Roe, 'A Theory of Path Dependence in Corporate Governance and Ownership' (2000) 52 Stanford Law Review 127.

111 Bebchuk and Roe (n 110).

112 Ibid 132.

113 Tan and Wang (n 101) 147.

114 J F Huchet and X Richer, 'China in Search of an Efficient Corporate Governance System: International Comparison and Lessons' (Centre for Economic Reform and Transformation, Herriot-Watt University, Edinburgh, Discussion Paper No 99/01, 11 February 1999).

115 R Tomasic and N Andrews, 'Minority Shareholder Protection in China's Top 100 Listed Companies' (2007) 9 Australian Journal of Asian Law 88; see also H Cai, 'Bonding, Law Enforcement and Corporate Governance in China' (2007) 13 Stanford Journal of Law, Business and Finance 82.

116 M Xu and S Neftci, China's Financial Markets (Elsevier 2007) 218. 
remote distance from business operation in China make these reforms even more necessary. The rule-oriented protection of minority shareholders in the domain of corporate law shows its merits in comparison with market forces in China.

There is another argument based on path dependence theory that could explain the relationship between the unique corporate governance system in China and its derivative claim system. In terms of problems funding the litigation costs, a solution that has been advanced and practised elsewhere is the establishment of a foundation that processes a certain amount of the shares from each listed company in that jurisdiction. ${ }^{117}$ Corporate governance-related litigations funded by similar non-profit organisations have proved reasonably successful in Taiwan, Japan and South Korea. ${ }^{118}$ However, it is doubtful whether this system could be enforced in China because of the Chinese corporate governance and business organisation structures. The transplant of the system into China would be hindered by the government's tight control over civil society instructions. ${ }^{119}$

More generally speaking, China's listed companies face a set of very different ownership, business and financial conditions in comparison with companies operating under the Anglo-American model, and institutional conditions for the successful operation of the Chinese corporate governance framework are either absent or undeveloped. ${ }^{120}$ Fiduciary duties of directors are not clearly addressed in CCL 2006 and issues of standards of liability for independent directors and directors in general remain unclear. ${ }^{121}$ The legal system of the People's Republic of China, with little more than half a century's history, is still in its infancy compared with many continental European or Anglo-American law systems. The division between the supervisory power of the Chinese Securities Regulatory Commission and the authority of stock exchanges is unclear, leading to confusion in the regulation of the securities market and corporations. ${ }^{122}$ The enforcement of Chinese law is regarded as one of the most challenging problems for the government, despite the high priority which has been placed on judicial development.

The enforcement of law and regulations for corporate governance will also be different in China than they are elsewhere. Little judicial independence can be observed even in modern China because the judiciary is 'parallel to rather than superior to, other units of the Chinese bureaucracy'. ${ }^{23}$ The courts in China are 'people's courts', they are financed by government and are administratively and institutionally accountable to the government. ${ }^{124}$ There is a lack of thorough understanding and sufficient experience on the part of

117 P Jiang, The Development of Corporate Law from the 19th to the 20th Century (Gongsifa Cong 19 Shiji Dao 20 Shiji de Fazhan) in F Guo and J Wang, A Comprehensive Study of Company Law Reform (Gongsifa Xingai Zongheng Tan) (Beijing: Law Press China 2000) 204.

118 C J Milhaupt, 'Nonprofit Organisation as Investor Protection: Economic Theory, and Evidence from East Asia' (2004) 29 Yale Journal of International Law 169.

119 Clarke (n 84) 55.

120 O K Tam, 'Ethical Issues in the Evolution of corporate governance in China' (2002) 37(3) Journal of Business Ethics 303, 311.

121 D C Clarke, 'The Independent Directors in Chinese Corporate Governance' (2006) Delaware Journal of Corporate Law 125, 224.

122 Wei (n 82) 485.

123 M A Layton, 'Is Private Securities Litigation Essential for the Development of China's Stock Market?’ (2008) 83 New York University Law Review 1948, 1957-58.

124 Ibid 1958. 
directors, judges, ${ }^{125}$ solicitors and other practitioners regarding actual legal meanings, the nature and scope of their duties and how to enforce them through management policies. However, transplanting the derivative action system to China and making it enforceable will involve a long process based on a more solid and thorough understanding of the nature and scope of the directors' duties codified in CCL 2006, together with more expertise from judges and more in-depth academic research. Thus, whether shareholders' derivative action in CCL 2006 will truly enable shareholders to recover from mismanagement remains uncertain, and the accessibility of the system is particularly important in China due to the doubtful ability of the courts, as well as a lack of confidence in the courts on the part of minority shareholders and the public. China is the first Communist nation in the world to have a stock exchange, and the only socialist country to initiate the creation of a marketstyle modern enterprise system since 1990, through a corporatisation and shareholding framework but without privatising its SOEs. China needs a unique system of its own, shaped by the 'socialist market economy with Chinese characteristics'. This is also the case for a putative Chinese derivative action system.

\section{Conclusion}

Clark labelled the shareholder derivative suit as 'one of the most interesting and ingenious accountability mechanisms' for large companies. ${ }^{126}$ The introduction of the shareholder derivative action system in CCL 2006 has been regarded as a milestone for CCL and corporate governance reform. ${ }^{127}$ The new CCL 2006 offered many changes to various aspects of corporate governance and made it easier to start and conduct business by using corporations as a form of business organisation in China. The statutory derivative action framework enacted in China is, just like most of its predecessors, designed to correct the difficulties faced by minority shareholders who are faced with controllers who have misused their power within the company. With the dramatic increase in investments from foreign institutional investors in the emerging market, from US\$25 billion in 1990 to US\$300 billion in 2005, ${ }^{128}$ the acceptance of shareholder derivative litigation demonstrates the way in which emerging economies like that in China are seeking to attract domestic and foreign investors and compete with developed economies for capital. ${ }^{129}$ The new law also enhances the protection of disadvantaged groups such as minority shareholders and various stakeholders, addressing some of the issues arising from ineffective corporate governance systems and the abuse of power from boards and controlling shareholders. The derivative action system offers a legitimate platform to redress corporate misbehaviour in the interests of minority shareholders and the company at large.

125 With more than 170,000 law graduates every year gaining their LLB degree from universities, the qualifications of Chinese judges are worrying. Only $19.1 \%$ of them have a Bachelor's degree or higher, while many have not graduated from law school and a substantial number graduating do so through continuing education; see M Zhang, 'International Civil Litigation in China: A Practical Analysis of the Chinese Judicial System' (2002) 25(1) Boston College International and Comparative Law Review 59, 94-95.

126 R C Clark, Corporate Law (Aspen Publishers 1986) para 15.1.

127 N Krause and C Qin, 'An Overview of China’s New Company Law' (2007) 28 Company Lawyer 316, 316, 319; see also M Gu, Understanding Chinese Company Law (2nd edn, Hong Kong UP 2010) ch 6.

128 T Moss, V Ramachandran and S Standley, Why Doesn't Africa Get More Equity Investment? Frontier Stock. Market, Firm Size and Asset Allocation of Global Emerging Market Fund (Centre for Global Development Working Paper No 112 2007) 1, <http://ideas.repec.org/p/cgd/wpaper/112.html>.

129 A M Scarlett, 'Investors Beware: Assessing Shareholder Derivative Litigation in India and China' (2011) 33 University of Pennsylvania Journal of International Law 173, 177. 
Compared with pre-existing legislations, uncertainties about derivative suits in China ${ }^{130}$ have been reduced by the amendments brought in by CCL 2006. However, in terms of the newly established derivative action, ineffective aspects within the new statutory system stipulated in CCL 2006 still hinder the enforcement of an investor-friendly derivative lawsuit system in China. Doctrinal and political obstacles severely limit the function and efficacy of the derivative suit as a device for policing management malfeasance. ${ }^{131}$ These deficiencies rest on standing, scope and the cost of litigation. Reform suggestions have been made regarding each deficiency of the system, with the purpose of building a new and efficient framework by maintaining a balance between granting rights to minority shareholders while at the same time avoiding frivolous suits. The suggestions were made clearer by discussions of theoretical support from corporate governance theories including agency theory and path dependence theory. It is concluded that derivative action in China must include a few specific local variations to fit with the many unique characteristics of China's history, economy and society. The relationship between the interests of shareholders, stakeholders, the company, directors, agency theory and stakeholder theory can be seen in the Figure 1.

Priority should be placed on encouraging shareholders to take derivative action and address the misconduct of company management teams, rather than on restricting the scope of derivative action. ${ }^{132}$ However, there is still a long way to go before China can fully adopt a derivative action litigation system with efficient Chinese civil procedures, thereby offering shareholders better and more practical remedies.

\section{Figure 1: Corporate actors, corporate decisions and corporate governance theory}

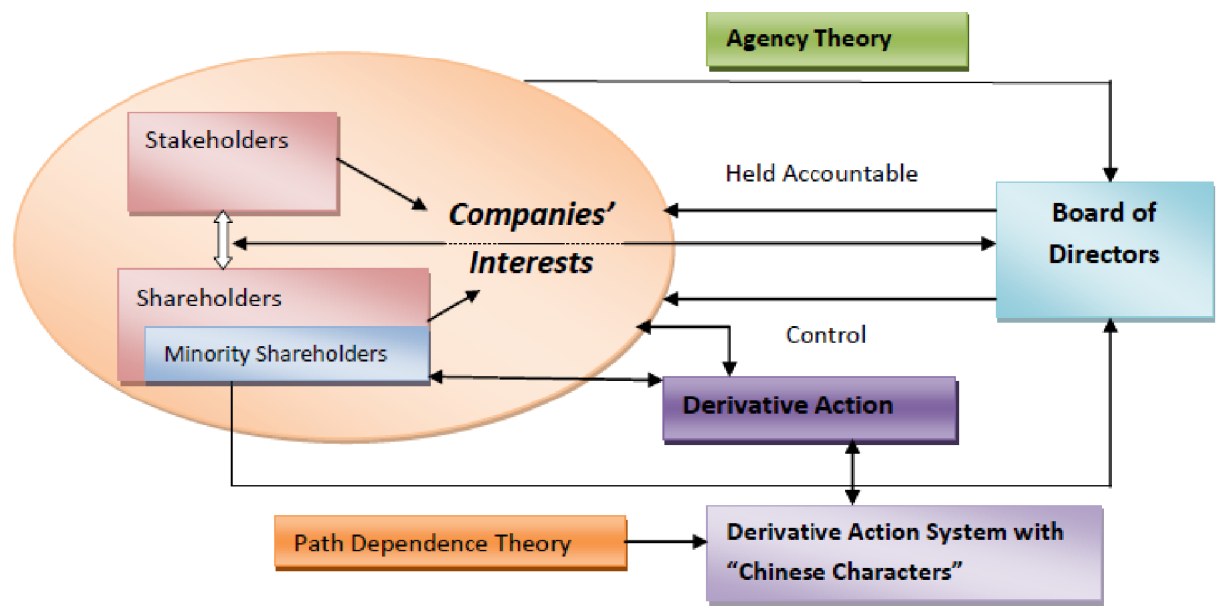

130 The uncertainties can be observed in statutory instruments and also in cases, for example: arts 111 and 63 of CCL 1993; art 42 of Chinese Securities Law 1999, art 4 of Principles of Corporate Governance for Listed Companies; Zhangïagang Fiber Co case (1994); Shanghai Yanshong Water Company case (1997); Xiamen Xinda Network Co case (1997); Zhejiang Wu Fang Zhai Co case (2001); and the more recent Sanjiu Pharmaceutical Co case (2003).

131 Clarke (n 84) 47.

132 G Li and C Wang, 'Issues on Adjudicating Cases of Company Law Litigation: Stories after the Enforcement of Chinese Company Law 2006' available (in Chinese) <www.civillaw.com.cn/article/default.asp?id=46000>. 
